\title{
Perception of Family Careers about Microcephalia: an Analysis through Adaptation Theory
}

\section{Percepção dos Cuidadores Familiares Acerca da Microcefalia: uma Análise por Meio da Teoria da Adaptação}

\author{
Ana Paula de Sousa Suassuna ${ }^{\mathrm{a}}$; Luanna Gomes da Silva ${ }^{\mathrm{b}}$; Izabel Cristina Santiago Lemos de Beltrão*c; Maria Eugênia \\ Alves Almeida Coelho ${ }^{\mathrm{d}}$; Célida Juliana de Oliveira ${ }^{\mathrm{e}}$; Dailon de Araújo Alves ${ }^{\mathrm{f}}$ \\ ${ }^{a}$ Integrateal Faculty of Patos, Post-graduate Studies in Gynecology and Obstetrics. CE, Brazil. \\ ${ }^{b}$ Regional University of Cariri. Stricto Sensu Post-graduate Program in Nursing. CE, Brazil. \\ ${ }^{\circ}$ Federal Rural University of Pernambuco, Stricto Sensu Graduate Program in Ethnobiology and Nature Conservation College. PE, Brazil. \\ ${ }^{\mathrm{d}}$ Regional University of Cariri, Nursing Department. CE, Brazil. \\ ${ }^{e}$ Regional University of Cariri, Health Sciences Center, Nursing Department. CE, Brazil \\ fJuazeiro do Norte School of Medicine, Undergraduate Nursing Course. CE, Brazil. \\ *E-mail: izabel_santiago@hotmail.com \\ Recebido em: 26/10/2020 \\ Aprovado em:14/12/2020
}

\begin{abstract}
Ultimately, there has been an increase in the number of cases of newborns affected by microcephaly, knowledge of the caregiver's perceptions regarding the child with microcephaly may promote the construction of therapeutic plans by health professionals that meet the expressed current needs of the child and caregivers. Thus, the aim of the present study is to describe the family caregivers' perception about microcephaly, using Callista Roy's adaptation theory. The research is descriptive, exploratory and with qualitative approach and was conducted at a School Clinic, located in the municipality of Juazeiro do Norte. The research participants were family caregivers of children diagnosed with microcephaly. Minayo's thematic analysis was used, supported by Roy's adaptation theory. Through data analysis two categories emerged: Knowledge and perception of family caregivers about microcephaly and family as support to cope with difficulties. It was observed that mothers, faced with the condition of their son with microcephaly, tend to develop a certain level of adaptation to make the situation less traumatic, making use of available social, medical care and family devices. Therefore, it is emphasized that health professionals need to act effectively in care, facilitating and strengthening effective adaptive responses.
\end{abstract}

Keywords: Microcephaly. Child, Family Caregiver. Nursing Theories.

\section{Resumo}

Nos últimos anos, o número de casos de recém-nascidos acometidos por microcefalia aumentou vertiginosamente, o conhecimento das percepções do cuidador em relação à criança com microcefalia pode fomentar a construção de planos terapêuticos por parte dos profissionais de saúde que atendam às necessidades vigentes expressas da criança e dos cuidadores. Assim, objetivo do presente estudo é descrever a percepção dos cuidadores familiares acerca da microcefalia, à luz da teoria da adaptação de Callista Roy. A pesquisa é descritiva, exploratória e com abordagem qualitativa. A pesquisa foi conduzida em uma Clínica Escola, localizada no município de Juazeiro do Norte. Os participantes da pesquisa foram cuidadores familiares de crianças com diagnóstico de microcefalia. Utilizou-se a análise temática de Minayo, sendo sustentada pela teoria da adaptação de Roy. Através da análise dos dados surgiram duas categorias: Conhecimento e percepção dos cuidadores familiares sobre a microcefalia e a família como apoio no enfrentamento das dificuldades. Observou-se que as mães, frente à condição do filho com microcefalia, tendem a desenvolver certo nível de adaptação para tornar a situação menos traumática, valendo-se dos dispositivos sociais, assistenciais e familiares disponiveis. Destaca-se, portanto, que os profissionais da saúde precisam atuar de forma eficaz na assistência, facilitando e fortalecendo as respostas adaptativas eficazes.

Palavras-chave: Microcefalia. Criança. Cuidador Familiar. Teorias de Enfermagem.

\section{Introduction}

Microcephaly is a neurological condition that has a cephalic perimeter lower than expected for age and sex. It may be associated with brain malformation. It has been associated with several factors, from the mother's malnutrition and drug abuse, to infections during the gestational period, such as rubella, toxoplasmosis and cytomegalovirus, among others. A diversity of metabolic and/or genetic abnormalities and syndromes, environmental aggressions and causes still unknown, may also affect the brain development and be associated with the disease ${ }^{1}$.
The central nervous system of the embryo is considered to be at greater risk for complications caused by infectious processes and it remains susceptible throughout pregnancy. Thus, the severity profile of complications arising from infection, such as Zika virus, will depend on several factors, namely: stage of conceptual development, pathogenic mechanism of etiological agent and fetal maternal genotype ${ }^{2}$.

According to the Ministry of Health ${ }^{3}$, microcephaly can be classified into two categories: congenital microcephaly, also known as "primary microcephaly", which is present at birth and postnatal microcephaly also called "secondary microcephaly", is related to head circumference growth 
failure after birth.

In turn, children with chronic conditions need constant and often complex care at home, constituting a challenge for their family caregivers. Such care should be developed on the basis of the guidelines of health professionals ${ }^{4}$.

In this sense, Callista Roy's adaptation theory views the person as an adaptive being to different health conditions. Thus, when born in a family environment, a child with special needs, the whole family needs to adapt to meet the needs of this child.

Tremarim, Gawleta and Rocha ${ }^{5}$ understand the child and family as a system that has the capacity to adapt to the new situation, which is permeated by the occurrence of numerous stimuli. The behavior presented by both, in the face of the same stimuli, will depend on the mechanisms of coping or individual control processes, but not always, it is possible to achieve adaptation, having as results, ineffective behaviors to deal with the situation.

It is worth pointing out that, in several cities, support groups or extension projects were created to help and support children affected by microcephaly and their parents, these groups are very important, because parents can share experiences, difficulties and challenges in caring for their children, in addition to having support from qualified professionals.

The diagnosis of a child with microcephaly brings about a new reality for the family, especially among parents. Adaptations and the negotiation of new roles become easier for the family when it accepts the child and begins to participate in the care process ${ }^{6}$.

Therefore, since in recent years the number of cases of newborns affected by microcephaly has increased dramatically, the knowledge of the caregiver's perceptions regarding the child with microcephaly, can promote the construction of therapeutic plans by health professionals that meet the current expressed needs of the child and caregivers.

Thus, the present study aimed to describe the perception of family caregivers about microcephaly, considering the Callista Roy's adaptation theory.

\section{Material and Methods}

This is a descriptive and exploratory research, with a predominantly qualitative approach. The data were organized through the thematic analysis of Minayo, which is divided into three stages: Pre-analysis, the material exploration and treatment of the results obtained and interpretation?

The place where the research was carried out is the Clinic School of Physiotherapy of Medicine School of Estácio of Juazeiro do Norte (Estácio FMJ), located in the municipality of Juazeiro do Norte, in the state of Ceará. In this institution, 11 children with microcephaly were assisted during the research period, and they come from Juazeiro do Norte and surrounding cities.
The research participants were family caregivers of children diagnosed with microcephaly, who were receiving treatment at the Clinic aforementioned. Nine caregivers participated in the study. In addition, the following aspect was considered as inclusion criteria in the study: Living directly with the child, and the caregiver must also reside in the child's home environment.

However, the following exclusion criteria were adopted: Not attending the clinic on days of interview and/or if they deny participating in the research.

After the selection, the participants who were chosen and voluntarily agreed with the research objectives were invited to read and sign the Free and Informed Consent Term (TCLE) or the Free and clarified consent term (TALE) if the participant was under the age of 18 , were interviewed individually and the information collected served as a source for the analysis and interpretation of the subject under study, where the identity and confidentiality of the data provided were respected at all times.

The semi structured interview was used to perform data collection, guided by a pre-elaborated interview script, which approached subjective questions with the purpose of exploring better the knowledge that the interviewee had regarding the proposed theme.

The interviews were applied individually and in a reserved environment. In the data collection process, the participants' names were omitted and pseudonyms were assigned for the classification, with no possibility of identifying them.

After the end of the interviews, all the contents originated from the recordings were transcribed and analyzed later.

Regarding the ethical aspects, the present study was submitted to the Research Ethics Committee through the project registration in Plataforma Brasil. With a favorable opinion number 1.881.268.

In order to guarantee the right of the research participants, all the parameters of resolution number 466/2012, of the National Health Council/Ministry of Health, which regulates research on human beings, were observed ${ }^{8}$.

\section{Results and Discussion}

\subsection{Socio-demographic profile of caregivers and children}

Data analysis allowed us to outline the caregivers' characteristics according to sex, age, schooling, profession, marital status, family income and religion.

The study was carried out with nine family caregivers of children diagnosed with microcephaly, who receive physiotherapeutic follow-up at the Clinic School of Physiotherapy of Estácio FMJ, being all female caregivers. The participants were aged between 20 and 34 years of age, and all of them represented the children's parents.

The vast majority had completed high school education (five participants), one with complete upper and one incomplete upper, but the predominant occupation was 
maid $(55.55 \%)$, because most caregivers reported having interrupted the work activities to dedicate themselves to the child. It is worth pointing out that in $55.55 \%$ of the cases, the family income consisted of only one minimum wage, most of which came from the benefit offered by social security.

The religion that predominated among the interviewees was Catholic (88.88\%), only one reported being evangelical. Moreover, of the nine participants, only four had a partner (three were married and one in common law marriage), the others had no marital bond, three single, one divorced and one widow.

Data analysis allowed the children's characteristics to be delineating according to sex, age, place of birth/ residence, cause of microcephaly, place of treatment/follow-up.

Children with microcephaly, children of women who participated in the study, at the time of the interviews, were between 10 months and 1 year and 7 months, the great majority being between 1 year and 1 month and 1 year and 6 months, corresponding to $77.77 \%$. Of the nine children with microcephaly, five were male and four were female.

It is worth pointing out that most children had the cause of microcephaly the Zika virus infection, only one was caused by hypoxia at the time of delivery, and two still had no definition of the cause.

\subsection{Knowledge and perception of family caregivers about microcephaly}

Several definitions were evidenced by caregivers regarding microcephaly, some with markedly biomedical perspectives and others with more subjective foundations. The following statements reveal these phenomena:

Microcephaly is the delay (sic) in the development of these children, everything will be late, walking, talking. (Mônica's mother )

It is a neurological limitation, and a brain reduction, that is what the doctors explain. (Mickey's mother)

Oh, it's a disease, kind of, that's it, it's a special child, it's going to always be special, it's going to depend on me forever, it's not going to be a normal child like the others. (Garfield's mother)

Microcephaly they (health professionals) explain that micro because the head is small and the brain does not develop either. (Ken's mother)

It was observed through certain testimonies that microcephaly for some caregivers is considered something new.

As they (health professionals) themselves speak, it is a new case, then they say: not even us know [...] it is a blind future. (Ken's mother)

It's new to everyone [...] microcephaly, mainly by Zika, for me it's a new thing, until then, it was barely heard about microcephaly. (Cinderela's mother)

In the course of the interviews, the caregivers reported the following complications that their children had related to microcephaly:

She is feeling these things (convulsions) [...]. (Mônica's mother )

It is a lot of thing that comes along with microcephaly, [...] because he has epilepsy, because he has spasm, he still has hydro, because where there is no brain, it is so small and then if fills with water. (Ken's mother)

He might walk and might not walk; he might speak and might not speak. (Jerry's mother)

\subsection{The family as support in coping with difficulties}

The family is an important source of support in facing difficult times, the main characters considered as support were: the child's father, aunts and grandparents. This can be noticed in the following statements:

There is my sister and my husband. (Mônica's mother )

His father helps, he does not help that much when he's

healthy, not, but when he's sick, he helps, he helps a lot.

(Ken's mother)

My family, my sister. (Lindinha's mother)

My family, so (sic) always with me, in whatever I need they are with me. (Garfield's mother)

It should be noted that, when asked about support to care for the child, it was common to report the mother as support.

My family, especially my mother. (Mickey's mother)

Only my Mother. (Cinderela's mother)

Yes, my Mother. (Ariel's mother)

An important factor realized in this study is that all children had women as caregivers, and these were their parents, in agreement with Silva ${ }^{9}$, who reports in her study that woman is mostly the primary caregiver.

It was observed that most children had as their cause microcephaly the infection with the zika virus, since the period when the interviewees were pregnant coincided with the epidemic of this virus in Brazil.

Therefore, the large number of cases of Zika-related microcephaly has been justified by the epidemic in the country since $2015^{9}$. In this sense, it is noteworthy that, still in 2015, the Ministry of Health recognized the relationship between the increase in the prevalence of microcephaly cases in Brazil and Zika infection during pregnancy ${ }^{1}$.

The speeches presented showed that the caregivers are well informed about what microcephaly is. It was also observed that in some cases, the caregivers' knowledge is acquired through the health professionals. This is important, because it is noted the commitment of these professionals to the family's knowledge regarding the disease.

Thus, the knowledge acquired about the pathology may serve as a strengthening of effective adaptive responses, since the family is prepared for manifestations or alterations that may happen to the child and also changes in daily life.

Thus, reinforcing that both these professionals and the other health professionals should increasingly provide guidance to family members and caregivers about health/ disease processes, providing that the person also becomes an author of his or her health and quality of life, strengthening ties between the team and the cares recipient, in addition, when well informed about his or her problem, the person has 
more possibilities to prevent complications.

Microcephaly is not a new "disease", however, as reported by the caregivers, the microcephaly caused by the Zika virus is actually a problem that had recent mydriatic and sanitary ascendance ${ }^{10,11}$.

Participants' propensity to associate microcephaly with commitment to neurological development and limitation was observed. Thus, corroborating what the literature states, because the child with microcephaly presents differentiated degrees of delay in neuropsychomotor development and a certain degree of mental retardation ${ }^{10}$.

According to Brunoni et al. ${ }^{12}$ the alterations that are often associated with microcephaly are related to intellectual deficit, in addition, other conditions that include epilepsy, cerebral palsy, delayed language and/or motor development, strabismus, ophthalmologic, cardiac, renal, urinary tract disorders, may also be related to this disease.

Reis $^{1}$ also states that the disease sequels so far are not fully known. However, it is known that the majority affected may manifest auditory impairment, vision and neuropsychomotor deficits of different degrees, and it is even possible to reach cerebral palsy signls ${ }^{3}$.

When the caregiver needs support in relation to the child, the maternal grandmother is the main helper, taking over the cares, thus constituting a secondary caregiver. It was also realized that the maternal family is constantly present in terms of support for the primary caregiver. Only in two cases, the child's father was referred to as the supporter of this caregiver.

The presence of the paternal figure in the family is very important for the children, regardless of social level, culture, or health condition, but when this child experiences a disease situation, this role is even more relevant, since the mother who plays the role of primary caregiver needs help to provide the care the child needs and the same does not suffer from the overload of taking care. On the other hand, according to Souza et $\mathrm{al}^{13}$, the number of parents who educate their children, without living with them on a daily basis, has been growing every day.

Thus, reflecting on the humanist values defended by Callista Roy, in the form of interdependence, it is possible to observe the patterns of human value, affection, love and affirmation, which occur through interpersonal relationships at both individual and group level ${ }^{14}$. Thus, the existence of group coping, that is, in family, is constituted in the use of the interdependence adaptive mode of the caregiver's adaptive system. Therefore, microcephaly is considered the input, or rather the stimulus.

\section{Conclusion}

In the course of the research construction, it was possible to learn about the stimuli and coping mechanisms used by caregivers and the socio-demographic profile of family caregivers and children.

The analysis of the testimonies was based on the theoretical model of Callista Roy's adaptation theory, which proved to be adequate for the study, since it considers the human being an adaptive system in the face of certain stimuli. Thus, mothers facing the condition of their child with microcephaly tend to develop a certain level of adaptation to make the situation less traumatic, using the social, healthcare and family devices available.

All the caregivers approached in the study are the children's parents, they demonstrated important knowledge regarding microcephaly, considering that they were guided by the health professionals, thus showing the commitment of these professionals to the caregivers' knowledge, which helps in coping and consequently contributes to the adaptation of these mothers.

The relevance of the results of this research and its important contribution to health professionals, who need to act effectively in care, facilitating and strengthening the effective adaptive responses for the coping with the situation experienced.

\section{References}

1. Reis RP. Aumento dos casos de microcefalia no Brasil. Rev Med Minas Gerais 2015;25:S88-S91. doi: 10.5935/22383182.20150101

2. Brasil. Ministério da Saúde. Protocolo de vigilância e resposta à ocorrência de microcefalia e/ou alterações do sistema nervoso central (SNC). Brasília: MS; 2015.

3. Brasil. Ministério da Saúde. Diretrizes de estimulação precoce: crianças de zero a 3 anos com atraso no desenvolvimento neuropsicomotor decorrente de microcefalia. Brasília: MS; 2016.

4. Tavares TS. A continuidade do cuidado às crianças com condições crônicas egressas de terapia intensiva neonatal: a perspectiva das famílias. Belo Horizonte: Universidade Federal de Minas Gerais; 2012.

5. Tremarin LA, Gawleta F, Rocha DLB. A teoria da adaptação sustentando o cuidado de enfermagem em hospital pediátrico: um estudo de caso. Cogitare Enferm 2009;14(3):569-74. doi: 10.5380/ce.v14i3.16192

6. Pinto RNM, Torquato IMB, Collet N, Reichert APS, Souza Neto VL, Saraiva AM. Autismo infantil: impacto do diagnóstico e repercussões nas relações familiares. Rev Gaúcha Enferm 2016;37(3):e61572. doi: 10.1590/19831447.2016.03.61572

7. Minayo MCS. O desafio do conhecimento: pesquisa qualitativa em saúde. São Paulo: Hucitec; 2014.

8. Brasil. Conselho Nacional de Saúde. Resolução n 466, de 12 de dezembro de 2012. Aprova normas regulamentadoras de pesquisas envolvendo seres humanos. Brasília: Diário Oficial da União, 2013.

9. Silva TCO, Barros V F, Hora, E C. Experiência de ser um cuidador familiar no câncer infantil. Rev. RENE 2011; 12(3):526-31.

10. Sá FE, Cardoso KVVC, Jucá RVBM. Microcefalia e Vírus Zika: do padrão epidemiológico à intervenção precoce. Rev Fisioter S Fun 2016;5(1):2-5.

11. Camargo KR. Zika, microcefalia, ciência e Saúde Coletiva. Physis 2016;26(1):9-10. doi: 10.1590/S0103- 


\section{1}

12. Brunoni D, Assis SMB, Osório AAC, Seabra AG, Amato CAH, Teixeira MCTV, et al. Microcefalia e outras manifestações relacionadas ao vírus Zika: Impacto nas crianças, nas famílias e nas equipes de saúde. Ciênc. Saúde Coletiva 2016;21(10):3297-3302. doi: 10.1590/1413-
812320152110.16832016.

13. Souza KSM, Smeha LN, Arend JC. A relação entre pai e filho(s) após a separação conjugal. Barbarói 2012;37:7-29.

14. George JB. Teorias de enfermagem: Os fundamentos à prática profissional. Porto Alegre: Artmed; 2000. 